International Journal of Advanced Academic Studies 2021; 3(4): 01-05

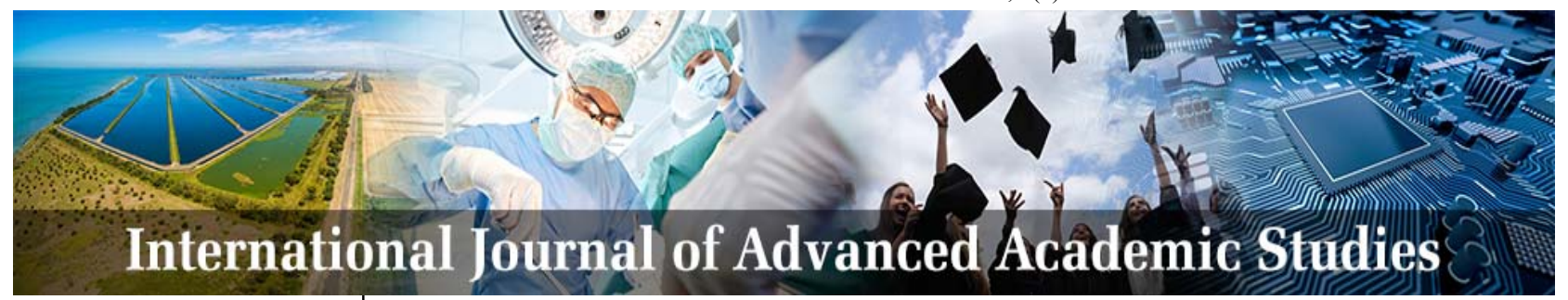

E-ISSN: 2706-8927 P-ISSN: 2706-8919 www.allstudyjournal.com IJAAS 2021; 3(4): 01-05 Received: 25-08-2021 Accepted: 28-09-2021

Monika Gupta

Research Scholar, Centre for European Studies, School of International Studies, Jawaharlal Nehru University, New Delhi, Delhi, India
Corresponding Author: Monika Gupta Research Scholar, Centre for European Studies, School of International Studies, Jawaharlal Nehru University, New Delhi, Delhi, India

\section{US-China ties from Trump to Biden and its implications on India's foreign policy}

\section{Monika Gupta}

DOI: https://doi.org/10.33545/27068919.2021.v3.i4a.625

\begin{abstract}
The paper makes an attempt to analyse US-China relationship from the era of Trump to Biden in the light of understanding its implications upon India and its foreign policy. The article looks at identifying various factors that remains the potential reasons of conflict between US and China and how it acts as an opportunity for India to diversify its global interests and positioning within world politics. The focus of the paper lies in understanding how the two emerging economic superpowers will be shaping international relations in the years to come and how India should place itself amidst these two differently aligned powers, considering the fact that India cannot afford to lose one at the cost of another especially when these two countries also happen to be India's top two largest trading partners. Drawing from the above framework, this paper is divided into different sections where the first part of the paper provides a glimpse into the US-China relations and how it has evolved since the beginning of the Cold war period. The second part of the paper throws light upon the US-China relations under Donald Trump and the impact it had on India's Foreign policy. The third and significant part of the paper takes a futuristic approach in understanding how Biden's Presidency is likely to shape US-China relationship over the next four years and what shall be its impact upon India's Foreign Policy. The fourth and the final part shall focus upon the findings of the paper and discuss apt conclusions.
\end{abstract}

Keywords: United States, China, India, Indian foreign policy, Biden, trump, economic powers

\section{Introductions}

With Joe Biden coming to power in January 2021, the entire world is looking up to his tenure in terms of how United States (US) will lead in shaping the global dynamics especially amidst a pandemic. United States being a hegemonic global superpower plays an influential role in not only defining the politics and foreign policy of the United States itself but also in defining the politics of various underdeveloped and developing economies. Before the Biden era, the tenure of Donald Trump as the US President was full of chaos, challenges and uncertainty in terms of US's relations with different countries across the world particularly China. Hence, the new government in US looked upon with hopes and aspirations not only by the people of the US but also by other countries of the world.

In the above context, this paper shall discuss the US-China relationship from Trump to Biden- its prospects and challenges and what are its likely impact on Indian foreign policy. The paper is divided into four parts where the first part discusses a brief history of US-China relations during the Cold War period. The second part of the paper discusses US-China relations during the Trump era and its implications on Indian Foreign Policy. The third and significant part of the paper discusses how US-China relationship under Joe Biden will shape Indian Foreign Policy in the next five years. The last and the final section will focus on the findings of the paper and discuss apt conclusions.

\section{US-China Relations- Since the beginning of the Cold war}

The time from 1945 onwards or rather the beginning of the Cold war is a time period when the two countries have substantially engaged with each other on one or the other grounds. In the aftermath of the Cold war, in October 1949, People's Republic of China (PRC) came into existence. However, US did not formally recognised PRC till the year 1979. For whole long thirty years, US did not recognise the People's Republic of China (PRC) and instead maintained diplomatic ties with the Republic of China government in Taiwan. In fact, Republic of China was the part of the United Nations for a long time even after coming of the PRC as United States always opposed it. The relations between the two countries got restrained during the 1950 Korean War when Soviet and China backed North Korean army invaded South Korea which was then backed by the United States. 
The US led forces pushed back the invading North Korean army and started marching towards the China-North Korean border despite repeated warnings by China. In return, a massive counterattack was launched by China which gave a heavy blow to the US led invading forces resulting into the defeat of the US Eighth Army which is by far the longest retreat of any American military unit in history. Since then, Korea has become a very important factor when it comes to analysing the US-China relationship (Fitzsimmons 2021) ${ }^{[4]}$. Next, during the Cold war period, there was another major war called the Vietnam War in the year 1962 which further strained the ties between the two countries. In this war, PRC whole-heartedly supported the communists in Vietnam with both men and money in a war against the United States and even went on to undertake some reconstruction activities in North Vietnam that was devastated due to attacks from the American side. Although the then leader of PRC, Mao Zedong declared that PRC doesn't want to be a part of this Vietnam War and doesn't want itself to be involved in the affairs of the United States but it was clear that indirectly PRC did provide a support to the North Vietnam against the United States (Fitzsimmons 2021) ${ }^{[4]}$.

However, the end of the 1960s brought about a period of transformation in the relations between the two countries. The then American President Johnson decided to curb down the consequences of the Vietnam War which was taken positively by China as it gave the hint that USA doesn't want to expand their influence in the Asian region. On the other hand, at the same time, USSR became a more serious threat for China because of its interference in Czechoslovakia to replace the Communist government. The Sino-Soviet border conflict in 1969 further aggravated the situation when China was all isolated and knew that having good relations back with the United States was the only option available as it was the Cold War that was going on, with none of the two superpowers on China's side to back them up in the international affairs (Gerson 2010) ${ }^{[5]}$.

However, in the $1970 \mathrm{~s}$, the relations between the two countries significantly changed under the Nixon's regime, the then US President. During his tenure, the two countries entered into an era of negotiation after the hostile era of confrontation. Richard Nixon was completely in favour of having good and warm relations with China which he thought was advantageous for America's interests. Also, when in 1971, Nixon announced his foreign policy perspective towards China declaring that he had accepted an invitation to visit PRC, the first ever American President to visit People's Republic of China, aroused immense international concern and created shock waves around the world. Many countries feared the growing US-China ties especially the Soviet Union which was greatly shocked by US's informal recognition of the PRC. Therefore, it is said that Nixon's China policy was the most important thing that he did during his tenure as the President of the United States (Renouard 2012) ${ }^{[7]}$.

In 1973, in an effort to build formal diplomatic relations between the two countries, the US and PRC established the United States Liaison Office (UNSO) in Beijing and a subsequent PRC office was established in Washington. And finally on $1^{\text {st }}$ January 1979, United States formally recognised the People's Republic of China (PRC) and reiterated the fact that there is only one China and Taiwan is very much a part of it. After this formal recognition, both the countries tried their best to enhance their relationship on various grounds like defence, trade, education, cultural exchanges etc.

All the above events of the Cold War period showed various ups and downs in the relations between the two countries. However, just towards the end of the Cold War, the Tiananmen protests of 1989 came as a turning point in the relations between the two countries. China's extremely harsh and violent measures of suppressing the political protest in the country invited some serious criticisms from across the world including the United States who came up with various measures and economic sanctions against China and its extreme violation of human rights. After the Tiananmen Square issue, United States came down heavily on China and the relations appeared to be strained. However, during the Bush's tenure, Bush ensured constant engagement with China and did not wanted a conflicting relationship owing to vested economic interests.

However, during the Obama tenure, Sino-US relations had a good start but with major challenges swinging in soon and getting stabilized later towards the end of the tenure. It was evident during Obama's tenure that US could not tolerate the rise of China and hence President Obama resorted to "return to Asia Pacific" policy with the purpose of rebalancing (Canrong 2016) ${ }^{[1]}$.

This was a brief outlay of how US-China relationship progressed since the end of the Second World War and the subsequent sections discuss the relation between the two countries during the Trump and Biden era and its impact on Indian Foreign Policy.

\section{US-China relations under Donald Trump and its impact on India}

Donald Trump became the President of the United States in January 2017 for five years until January 2021. During this tenure, US took some major initiatives by challenging the established norms in International Relations. In the context of US-China relationship, the Presidents of both the countries met in November 2017 and this meet was looked upon as the most anticipated meet where the PresidentsTrump and Xi Jinping met to discuss the future course of relationship and some common areas to work together.

These areas were actually the issues of concern between the two countries since a long time like the issue of North Korea and its rising nuclear power, the trade relations between US and China, the military agreements between the two countries etc. What concerned international community were the facts that how 'real' are those growing ties between the two countries? The reason behind this concern was a long history that speaks more for the relations between the two countries. The two countries in the past have not shared a warmer relations and that is the reason that the world community is looking forward to every time when leaders from these countries meet. There were various speculations arising from this meeting between Mr. Donald Trump and Mr. Xi Jinping like- Are the two going to look forward to develop ties and make strong relations? Or is it just the North Korean issue that binds the two countries to indulge in dialogue with each other? Or the world community can witness another Cold war in the years to come between the world's hegemonic power and the growing hegemonic power? Or has the Cold war between US and China already begun?

Amidst this chaos and confusion, the first two years of Trump made it clear that the US and China can be 
favourable partners at world stage only if Beijing changes its rigid attitude on certain issues like discriminatory trade barriers, human rights and religious freedom, pressure on Taiwan, issues related to South-China Sea etc. Trump administration rarely believed in regular dialogues and considered them laborious and unproductive and were less about America and more about legitimising the Communist Party leadership in China and hence Trump resorted to unilateral and unidirectional American demands and approach made publicly thereby redefining Diplomacy (Dollar et al. 2019) ${ }^{[2]}$.

The trump tenure in US-China relations has been a turbulent one and it was in his tenure that the narrative of their relationship changed from "strategic partners to strategic competitors" and this is evident in the report that came just one month after Trump's visit to China in 2017 titled "National Defence Strategy Report 2017" where it explicitly mentioned about China saying- "China and Russia want to shape a world antithetical to US values and interests. China seeks to displace the United States in the Indo-Pacific region, expand the reaches of its state-driven economic model and reorder the region in its favour". This was perceived by Trump administration as a failure of the prolonged 'engagement strategy' with China as China only believed in its vested interests at the cost of the decline of the US power (Pilipey 2020) ${ }^{[6]}$.

As Trump's tenure was marching towards the end, he adopted a rigid and 'sledgehammer' approach towards the US-China relations. This included adopting a unilateral trade policy towards China as Trump believed that what China is doing can be called as a "predatory economics" in trade and technology and through his unilateral measuresTrump administration can greatly reduce US trade deficits with China and hence a trade deal was signed between the two countries which China basically used as a bait to keep bigger strategic issues off the table (Pilipey 2020) ${ }^{[6]}$.

Despite other simultaneous issues with the Trump Presidency, like deserting its allies (Canada, Japan, South Korea), reducing security commitment under NATO, withdrawing US leadership from global institution of climate and human rights and internal drift within the Trump administration greatly provided a new opportunity to China to rise itself at world stage and change global dynamics (Pilipey 2020) ${ }^{[6]}$. Thus, it can be said that by the time, Trump Presidency came to an end, China was already a bit stronger and powerful in terms of portraying itself at the world stage and the relations between the two countries reduced to a new low in the last few decades.

In terms of this strained US-China relations during Trump's Presidency and its impact upon India, it was witnessed that Trump wanted a greater role of India in the Asia-Pacific region and this is evident by the fact when Trump in his speech at Danang, Vietnam referred to the issue as IndoPacific instead of Asia-Pacific or Asia (Singh 2018) ${ }^{[10]}$. Thus, through China's invading and expansionist policies it is evident that it wants to take over and rule over entire Asia-Pacific which in turn poses a problem for the United States as it would reduce its supremacy over the region and hence US wants India (a friendly ally of US) to play a major role in the region. This comes as an opportunity for India to exploit to its own advantage.

During the Trump's tenure, India and the US also aligned together through Quad grouping with Australia and Japan as the other two members to keep the Indo-Pacific free, open and inclusive (Singh 2018) ${ }^{[10]}$ and indirectly keep China away from exerting its influence and hence these developments were very much in India's favour. Also, at the same time, the Doklam issue emerged as a reason of conflict between the India-China relations and India wanted no stone unturned to counter China's growing expansionary policies either within the territory of India or in South China Sea from where over 55\% of India's trade passes. Thus, it is to the advantage of both India and US that the Asia Pacific region (as China prefers to Call) has greater role of India than China and preferably be called as Indo-Pacific.

In another issue of US through its unilateral trade policy, taking some hard and strict measures against Chinese manufacturers was indirectly boosting Indian economy. It would benefit India in two ways as Shashi Tharoor rightly pointed out saying "If the US and China don't get along, the US will turn increasingly to India as a large Asian actor"; and China, if its market contracts, will need to diversify its markets and investment outlets, including towards India" (Singh 2018) ${ }^{[10]}$. Thus this provides a big boost to India's huge market and the opportunities it offers for manufactures and investors.

Thus the end of Trump era left behind a strained US-China relationship but a favourable US-India relationship with varying opportunities for India to counter China's rise and influence either in the Asia-Pacific or within South Asia and its neighbourhood particularly.

\section{US-China relations under Joe Biden and its impact on India}

Joe Biden came into power in January 2021 and has to deal with many challenges simultaneously including the mistakes of the turbulent Trump era, the on-going Pandemic and the very recent Afghanistan crisis. Amidst this, every country in the world looks up to the Biden era with hope, peace and stability and so is the case with India. It has been the history that any changes, positive or negative in the US-China relations have affected India's foreign policy and with the similar array of both fears and tranquillity, the next five years of Biden and its relation with China will have a strong bearing upon India and its foreign policy.

There were many speculations regarding Biden making up for the mistakes done during the Trump Presidency, for instance, with respect to improving relations with different countries around the world. However, Biden did make an effort in that direction resolving issues with many countries like Iran, Russia, Latin America etc. However, situation with China remains the same - intense and strained like before. The Biden administration did not reverse any decision or sanctions of the Trump presidency against China. However, Biden's tough stand against China goes back to the election campaign days when Trump and team portrayed Biden as having a soft approach towards China and its way of dealing with the Pandemic. Hence in order to ensure strict compliance with the election agenda, Biden seems to be adopting a firm stand against China especially on issues related to Uyghur Muslims, South China Sea, Chinese policies towards Tibet, Hong Kong and Taiwan etc. (Economic Times 2021) ${ }^{[3]}$.

It is beyond doubt that both China and United States are the world's growing economies and both are competing against each other to become the $21^{\text {st }}$ centuries' hegemonic superpower with no side following a policy of negotiation or contraction. Biden officials clearly say that their actions are 
a result of China's aggressive behaviour and they are trying their best to keep the relation of competition and not conflict. Chinese actions such as not cooperating in an investigation on the origin of the Covid-19 outbreak, military incursions into Taiwan's airspace, curbing freedom rights in Hong Kong etc. have left no choice with the Biden administration than to take strict measures against China (Wadhams et al. 2021) ${ }^{[11]}$. Thus, one can understand that in the next five years, the relations between US and China will not be at ease and the subsequent years will be shaping the global dynamics as well.

Most important part of the article lies in the fact that what will be the likely impact of this US-China relationship under Biden upon India's foreign policy. There are many dimensions and perspectives to look at from India's point of view. A strained US-China relation as explained during the Trump presidency is likely to benefit India both strategically and economically. India is also a part of QUAD, consisting of US, Australia and Japan and it is considered as an "Asian NATO" where India has potential to not only increase its engagement in the Asia-Pacific but also counter China's growing influence in the region with the help of powerful allies like the United States. Although, China has denied and sees no prospects in QUAD as an Asian NATO (Saran 2021) ${ }^{[8]}$ but there is no doubt that a rising Quad will be conflicting to Chinese interests in the region.

Another interesting factor under Biden's presidency is the fact that since his Vice-President days during the Obama tenure, Biden has always shown a very positive approach in its dealing towards India especially in terms of defence, terrorism, economic pacts, Indo-Pacific region and visa and immigration rules (Sen 2020) ${ }^{[9]}$. It is believed that a similar trend of support and cooperation should be rendered by the Biden administration towards India and which in turn would place India at an advantageous position in the world affairs. In the next four years of Biden's presidency, the US and China would be competing with each other for their vested economic interests and shall be major global players in world politics. India cannot afford to lose one at the cost of the other considering the huge trade relations it shares with both China and the United States. Both the US and China are India's top two trading partners respectively and hence India cannot loose either of them. Thus, in the subsequent years, it would be important for India to maintain a balance and make use of sound diplomacy in dealing with either China or United States. The position of India globally becomes critical especially in the light of the fact that historically India has always chosen to remain non-aligned and hence aligning with either side- United States or Russia backed China would have serious consequences for India. It has been witnessed recently when the United States openly claimed to impose sanctions on any country that does Business with Russian Defence Military complex. In such a scenario of India buying S-400 air-defence system from Russia towards the end of 2021 could impose serious consequences for India globally.

\section{Conclusion}

This article made an attempt to analyse Indian Foreign policy in the light of US-China relationship. The article makes an attempt to not only look at the present state of affairs but also the past and the future. It discusses significant developments in India's foreign policy during the Trump era and how it has been carried forward during the era of Joe Biden. The article looks at India's global positioning from a multiplicity of factors including its position in the Indo-Pacific, within the neighbourhood, in terms of non-aligned approach and also international positioning of India in world politics.

It is clearly evident that both United States and China are two rising powerful economies and since history their relationship has played a pivotal role in shaping global power dynamics and always had a significant impact upon Indian foreign policy. It can be inferred from the discussion above that the present state of relations between US and China presents a great opportunity for India to diversify its global outreach both politically and economically considering the favourable attitude of Biden led administration towards India. But at the same time, India needs to be cautious of not falling into the trap of being 'aligned' with one at the cost of the other as it would pose serious threat to India's economic interests and would be detrimental to its political and strategic interests too.

\section{References}

1. Canrong J. How America's relationship with China changed under Obama 2016. World Economic Forum, 14 December, available online, URL:

https://www.weforum.org/agenda/2016/12/americachina-relationship/.

2. Dollar D, Hass R, Bader JA. Assessing US-China relations 2 years into the Trump Presidency 2019. Brookings, 15 January, available online, URL: https://www.brookings.edu/blog/order-fromchaos/2019/01/15/assessing-u-s-china-relations-2years-into-the-trump-presidency/.

3. Economic Times. Joe Biden brings no relief to tensions between US and China 2021. Available online, URL: https://economictimes.indiatimes.com/news/defence/joe -biden-brings-no-relief-to-tensions-between-us-andchina/articleshow/81306319.cms? from $=\mathrm{mdr}$

4. Fitzsimmons D. Timeline: Major events in US-China relations since 1949, Aljazeera 2021. Available online, URL:

https://www.aljazeera.com/news/2021/7/25/timelinemajor-events-in-us-china-relations-since-1949.

5. Gerson M. The Sino-Soviet Border Conflict: Deterrence, Escalation and the Threat of Nuclear War in 1969, Center for Naval Analyses 2010. Available online, URL: https://www.cna.org/cna_files/pdf/d0022974.a2.pdf.

6. Pilipey R. Trump took a sledgehammer to US-China relations. This won't be an easy fix even if Biden wine, The Conversation 2020. Available online, URL: https://theconversation.com/trump-took-a-

sledgehammer-to-us-china-relations-this-wont-be-aneasy-fix-even-if-biden-wins-147098.

7. Renouard J. The Nixon-Mao Summit: A Week that changed the world, Education about Asia 2012, 17(3). Available online, URL:

https://www.asianstudies.org/publications/eaa/archives/ the-nixon-mao-summit-a-week-that-changed-theworld/.

8. Saran S. As Biden shapes a new US policy, China changes tack on ties with India, the Print 2021. Available online, URL: https://theprint.in/opinion/asbiden-shapes-a-new-us-policy-china-changes-tack-onties-with-india/610139/. 
9. Sen S. How does Joe Biden's win affect the Indo-US relationship? DNA 2020. Available online, URL: https://www.dnaindia.com/india/report-us-election2020-democrat-joe-biden-us-president-indiarelationship-2855180.

10. Singh T. Overview of US-China Relations under the Trump Administration, Vivekananda International Foundation Issue Brief 2018. Available online, URL: https://www.vifindia.org/sites/default/files/overview-ofus-china-relations-under-the-trump-administration.pdf.

11. Wadhams N, Mohsin S, Martin P. Biden's tough policy on Beijing means US-China relations are only going to get worse, The Print 2021. Available online, URL: https://theprint.in/world/bidens-tough-policy-onbeijing-means-us-china-relations-are-only-going-to-getworse/695574/ 